\title{
Effects of Calcium Carbonate and Its Purity on Crystallization and Melting Behavior, Mechanical Properties, and Processability of Syndiotactic Polypropylene
}

\author{
Pitt Supaphol, Wipasiri Harnsiri, Jirawut Junkasem \\ The Petroleum and Petrochemical College, Chulalongkorn University, Soi Chula 12, Phyathai Road, Pathumwan, \\ Bangkok 10330, Thailand
}

Received 15 November 2002; revised 15 February 2003; accepted 10 August 2003

\begin{abstract}
Calcium carbonate-filled syndiotactic poly(propylene) $\left(\mathrm{CaCO}_{3}\right.$-filled s-PP) was prepared in a self-wiping, co-rotating twin-screw extruder. The effects of $\mathrm{CaCO}_{3}$ of varying particle size $(1.9,2.8$ and $10.5 \mu \mathrm{m})$, content $(0-40 \mathrm{wt}$ $\%$ ), and type of surface modification (uncoated, stearic acidcoated, and paraffin-coated) on the crystallization and melting behavior, mechanical properties, and processability of $\mathrm{CaCO}_{3}$-filled s-PP were investigated. Non-isothermal crystallization studies indicate that $\mathrm{CaCO}_{3}$ acts as a good nucleating agent for s-PP. The nucleating efficiency of $\mathrm{CaCO}_{3}$ for s-PP was found to depend strongly on its purity, type of surface treatment, and average particle size. Tensile strength was found to decrease, while Young's modulus increased,
\end{abstract}

with increasing $\mathrm{CaCO}_{3}$ content. Both types of surface treatment on $\mathrm{CaCO}_{3}$ particles reduced tensile strength and Young's modulus, but improved impact resistance. Scanning electron microscopy (SEM) observations of the fracture surfaces for selected $\mathrm{CaCO}_{3}$-filled s-PP samples revealed an improvement in $\mathrm{CaCO}_{3}$ dispersion as a result of surface treatment. Finally, steady-state shear viscosity of $\mathrm{CaCO}_{3}-$ filled s-PP was found to increase with increasing $\mathrm{CaCO}_{3}$ content and decreasing particle size. (ㄷ 2004 Wiley Periodicals, Inc. J Appl Polym Sci 92: 201-212, 2004

Key words: syndiotactic; poly(propylene); crystallization; mechanical properties; processing

\section{INTRODUCTION}

In 1988, Ewen et al. ${ }^{1}$ reported a successful synthesis of stereo-regular and regio-regular syndiotactic poly(propylene) (s-PP) via a novel metallocene catalysis, instead of the traditional Ziegler-Natta catalysis. ${ }^{2}$ The discovery of this new catalyst system provided a new route for producing s-PP with improved purity and yield, which led to renewed interest for both scientific research ${ }^{3}$ and industrial applications. ${ }^{4-8}$

Studies of the crystallization process of semicrystalline polymers are of great importance in polymer processing, because the resulting physical properties are strongly related to the morphology and the extent of crystallization. Both quiescent isothermal and nonisothermal crystallization studies revealed that s-PP is a slowly crystallizing polymer. ${ }^{9,10}$ The addition of nucleating agents may help to overcome this problem by providing more nucleation sites, resulting in an increase in the overall crystallization rate, and hence reducing the processing time.

Nucleating agents can be divided into two types: inorganic and organic. Inorganic nucleating agents

Correspondence to: P. Supaphol.

Journal of Applied Polymer Science, Vol. 92, 201-212 (2004) (C) 2004 Wiley Periodicals, Inc. include talc, mica, barium sulfate $\left(\mathrm{BaSO}_{4}\right)$ and calcium carbonate $\left(\mathrm{CaCO}_{3}\right)$. Organic nucleating agents include sorbitals and their derivatives. Generally, $\mathrm{CaCO}_{3}$ is added to isotactic poly(propylene) (i-PP) to reduce the cost of the product, improve mechanical properties (e.g. modulus and heat stability), and enhance crystallization rate. To our knowledge, the only available reports on filled systems in s-PP, conducted by Mülhaupt and co-workers, ${ }^{11-13}$ are concerned with the mechanical and thermal properties, including phase behavior, of s-PP filled with glass beads and talcum.

In this study, the effects of $\mathrm{CaCO}_{3}$ of varying particle size $(1.9,2.8$ and $10.5 \mu \mathrm{m})$, content $(0-40 \mathrm{wt} \%)$, and type of surface modification (uncoated, stearic acid-coated, and paraffin-coated) on the crystallization and melting behavior, mechanical properties (tensile and impact properties), and processability (steadystate shear viscosity) of s- $\mathrm{PP} / \mathrm{CaCO}_{3}$ compounds were studied and reported for the first time.

\section{EXPERIMENTAL}

\section{Materials}

A commercial grade s-PP was produced and supplied in pellet form by ATOFINA Petrochemicals, Inc. (Houston, Texas, USA). Molecular characterization for this resin was carried out by Dr. Roger A. Phillips of 
TABLE I

Characteristics of $\mathrm{CaCO}_{3}$ Grades Used

\begin{tabular}{lcl}
\hline Trade Name & $\begin{array}{c}\text { Average particle size } \\
(\mu \mathrm{m})\end{array}$ & $\begin{array}{c}\text { Type of surface } \\
\text { treatment }\end{array}$ \\
\hline CALOFIL 400 & 1.9 & Uncoated \\
CALOFIL 100 & 2.8 & Uncoated \\
CALOFIL 50 & 10.5 & Uncoated \\
HICOAT 410 & 1.9 & Stearic acid-coated \\
HICOAT P-400 & 1.9 & Paraffin-coated \\
\hline
\end{tabular}

Basell USA, Inc. (Elkton, Maryland, USA). The results show the following molecular weight information: the weight-average molecular weight $\left(M_{w}\right)=153,000 \mathrm{Da}$ and the polydispersity $\left(M_{w} / M_{n}\right)=3.8$. Syndiotacticity of this resin was determined by ${ }^{13} \mathrm{C}$-NMR to exhibit the racemic triad content (\%rr) of $86.1 \%$ and the racemic pentad content $(\% r r r r)$ of $73.7 \%$, with a very low ethylene defect content of less than $0.5 \mathrm{wt} \%$.

Five commercial grades of $\mathrm{CaCO}_{3}$, kindly supplied by Calcium Products Co.,Ltd. (Thailand), were used as received. Particle characteristics of all $\mathrm{CaCO}_{3}$ grades (all with a density of $\approx 2.7 \mathrm{~g} / \mathrm{cm}^{3}$ ) used are listed in Table I. Characterization of all $\mathrm{CaCO}_{3}$ grades by $\mathrm{X}$-ray diffraction revealed that most of the as-received grades exhibited strong reflection peaks at $2 \theta=29.0$, 39.4 and $43.2^{\circ}$, corresponding to the characteristic peaks of calcite (JCPDS card no. 5-586), with the exception of the $10.5 \mu \mathrm{m}$ uncoated $\mathrm{CaCO}_{3}$ grade (CALOFIL 50), which exhibited strong reflection peaks, in addition to those of calcite, at $2 \theta=30.9,41.1$ and $51.0^{\circ}$, corresponding to the peaks of calcium magnesium carbonate or dolomite $\left[\mathrm{CaMg}\left(\mathrm{CO}_{3}\right)_{2}\right]$ (JCPDS card no. 36-426). This means that the as-received $10.5 \mu \mathrm{m}$ uncoated $\mathrm{CaCO}_{3}$ grade contained not only calcite but also dolomite.

\section{Sample preparation}

$\mathrm{CaCO}_{3}$ with varying particle size and type of surface treatment (uncoated, stearic acid-coated, and paraffincoated) was first dried in an oven at $80^{\circ} \mathrm{C}$ for $14 \mathrm{~h}$ and then pre-mixed with s-PP resin in a tumble mixer for $10 \mathrm{~min}$ in various compositional ratios, ranging from 0 to $40 \mathrm{wt} \%$ (approx. 0 to $18 \mathrm{vol} \%$ ). The pre-mixed compounds were then melt-mixed in a Collin ZK 25 self-wiping, co-rotating twin-screw extruder operating at a screw speed of $50 \mathrm{rpm}$ and a die temperature of $190^{\circ} \mathrm{C}$. The extrudate was cooled in water and cut into pellet form by a Planetrol 075D2 pelletizer. A Wabash $\mathrm{V} 50 \mathrm{H}$ compression press was used to prepare films and sheets of both neat s-PP and s-PP/ $\mathrm{CaCO}_{3}$ compounds for subsequent tests. The mold was first pre-heated in the compression press at $190^{\circ} \mathrm{C}$ for $5 \mathrm{~min}$ and then compressed with a 15 ton-force for another 5 min, after which it was cooled to $40^{\circ} \mathrm{C}$.

\section{Differential scanning calorimetry measurements}

Non-isothermal crystallization behavior of $\mathrm{CaCO}_{3}-$ filled s-PP samples was investigated on a PerkinElmer Series 7 differential scanning calorimeter (DSC). Temperature calibration was performed using an indium standard $\left(T_{m}{ }^{o}=156.6^{\circ} \mathrm{C}\right.$ and $\left.\Delta H_{f}^{o}=28.5 \mathrm{~J} / \mathrm{g}\right)$. Each sample of 3 to $6 \mathrm{mg}$ in weight, cut from the prepared compressed films, was sealed in an aluminum sample holder. The experimental procedure started with melting each sample at $190^{\circ} \mathrm{C}$ for $5 \mathrm{~min}$ and then cooling it to $-5^{\circ} \mathrm{C}$ at a rate of $10^{\circ} \mathrm{C} / \mathrm{min}$. After that, the sample was immediately subjected to heating at a rate of $20^{\circ} \mathrm{C} / \mathrm{min}$ to $160^{\circ} \mathrm{C}$. Both the crystallization exotherm and the melting endotherm were recorded for further analysis. All measurements were carried out in nitrogen atmosphere.

\section{Crystal structure and crystallinity measurements}

A wide-angle X-ray diffraction (WAXD) technique was used to determine the crystal modification and the apparent degree of crystallinity for both neat and $\mathrm{CaCO}_{3}$-filled s-PP samples prepared according to the conditions set forth for DSC measurements but without a subsequent heating step. Each sample was removed from the DSC sample holder and pasted onto a glass sample holder. The WAXD intensity patterns of the sample were then collected on a Rigaku Rint2000 diffractometer $\left(\mathrm{CuK}_{\alpha}\right.$ radiation, $\lambda=1.54 \AA$ ), equipped with computerized data collection and analytical tools. The X-ray source was operated at a voltage of $40 \mathrm{kV}$ and a filament current of $30 \mathrm{~mA}$.

\section{Mechanical property measurements}

Tensile strength and modulus for both neat and $\mathrm{CaCO}_{3}$-filled s-PP samples were measured on an Instron 4206 universal testing machine according to ASTM D 638-91 standard test method using a $100 \mathrm{kN}$ load cell and a $50 \mathrm{~mm} / \mathrm{min}$ crosshead speed. Izod impact resistance was determined on a Swick 5113 impact tester according to ASTM D 256-90b standard test method using $2.7 \mathrm{~J}$ pendulum and $124.4^{\circ}$ release angle. The results are reported as averages of the data taken from at least five specimens.

\section{Microstructural observation}

A JEOL 520-2AE scanning electron microscope (SEM) was used to observe the microstructure of the impactfractured surfaces of selected specimens obtained after impact testing. Each selected specimen was cut about $2 \mathrm{~mm}$ below the fractured surface, and the cut piece was stuck onto an aluminum stub. The sample was coated with gold using a vapor deposition technique and was subjected to observation by SEM. 


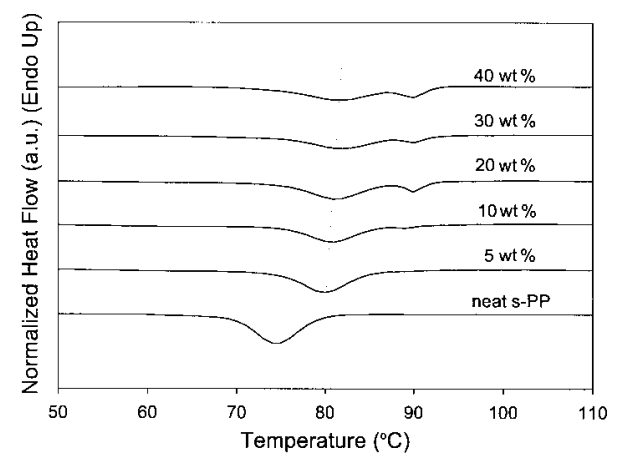

Figure 1 Non-isothermal crystallization exotherms for neat s-PP and $1.9 \mu \mathrm{m}$, uncoated $\mathrm{CaCO}_{3}$-filled s-PP samples at various filler contents (recorded at a cooling rate of $10^{\circ} \mathrm{C} /$ $\min )$.

\section{Shear viscosity measurements}

The steady-state shear viscosity for both neat and $\mathrm{CaCO}_{3}$-filled s-PP compounds was determined at $200^{\circ} \mathrm{C}$ in two different types of rheometers. An Instron 3213 capillary rheometer was used to study the steady-state shear behavior for both neat and $\mathrm{CaCO}_{3}-$ filled s-PP compounds at "high" shear rates (50 to $3,000 \mathrm{~s}^{-1}$ ). The capillary was a tapered type having a $45^{\circ}$ entrance angle. The barrel diameter was $9.525 \mathrm{~mm}$. The number 1860 capillary die with a $1.25 \mathrm{~mm}$ diameter and a $50.19 \mathrm{~mm}$ length $(L / D$ ratio $=40.15)$ was used in this study. An ARES Rheometric Scientific rheometer equipped with a parallel-plate fixture (8 $\mathrm{mm}$ diameter and $0.2 \mathrm{~mm}$ gap width) was used to study the steady-state shear behavior of these samples at "low" shear rates $(0.25$ to $25 \mathrm{rad} / \mathrm{s})$.

\section{RESULTS AND DISCUSSION}

\section{Non-isothermal crystallization and melting behavior}

Figure 1 shows non-isothermal crystallization exotherms for neat and $1.9 \mu \mathrm{m}$ uncoated $\mathrm{CaCO}_{3}$-filled s-PP samples at various filler contents (recorded at a cooling rate of $10^{\circ} \mathrm{C} / \mathrm{min}$ ). Apparently, the crystallization (peak) temperature $\left(T_{c l}\right)$ for the neat s-PP sample was observed at about $75^{\circ} \mathrm{C}$. The incorporation of $\mathrm{CaCO}_{3}$ particles shifted the $T_{c l}$ value toward a higher temperature, but, upon further increase in the $\mathrm{CaCO}_{3}$ content, the $T_{c l}$ value only increased slightly. Figure 1 shows two types of crystallization exotherm. The first is the single-peak type (the peak temperature of which denotes $T_{c l}$ ), which was found for neat s-PP and s-PP samples loaded with "low" contents of $1.9 \mu$ m-uncoated $\mathrm{CaCO}_{3}$ particles (approx. $0-10 \mathrm{wt} \%$ ), and the second is the double-peak type (the peak temperature of the low-temperature peak denotes $T_{c l}$, while that of the high-temperature peak denotes $T_{c h}$ ), which was only found for s-PP samples loaded with "high" con- tents of $1.9 \mu \mathrm{m}$ uncoated $\mathrm{CaCO}_{3}$ particles (approx. 20-40 wt \%). Interestingly, s-PP samples loaded with $\mathrm{CaCO}_{3}$ of larger particle sizes $(2.8$ and $10.5 \mu \mathrm{m})$ only exhibited a single-peak crystallization exotherm, regardless of the $\mathrm{CaCO}_{3}$ content.

In order to verify whether the occurrence of the double crystallization exotherms on s-PP samples loaded with "high" contents of $1.9 \mu$ m-uncoated $\mathrm{CaCO}_{3}$ particles (approx. 20-40 wt \%) was an artifact or not, two separate experiments were carried out. The first involved assessing the effect of repeated heating and cooling, while the second investigated the effect of melt-annealing time on the crystallization behavior of s-PP samples filled with $40 \mathrm{wt} \% 1.9 \mu \mathrm{m}$-uncoated $\mathrm{CaCO}_{3}$ particles. It should be noted that, in the first experiment, the melt-annealing time was $5 \mathrm{~min}$, while in the second experiment the melt-annealing time varied from 5 to $30 \mathrm{~min}$. The fusion temperature and cooling rate used in both experiments were fixed at $190^{\circ} \mathrm{C}$ and $10^{\circ} \mathrm{C} / \mathrm{min}$, respectively. According to Figure 2(a), it is clear that repeated heating and cooling affected neither the position nor the relative peak area of the two exotherms. In Figure 2(b), the effect of varying melt-annealing time on crystallization behavior of $40 \mathrm{wt} \% 1.9 \mu \mathrm{m}$ uncoated $\mathrm{CaCO}_{3}$-filled s-PP samples is illustrated. Clearly, variation in the meltannealing time did not affect the position of the two

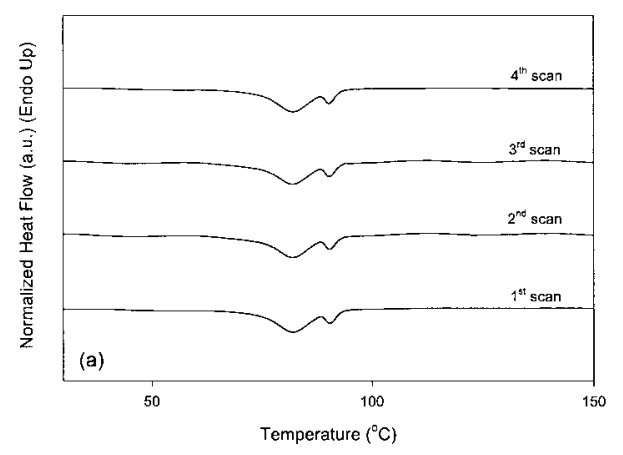

(a)

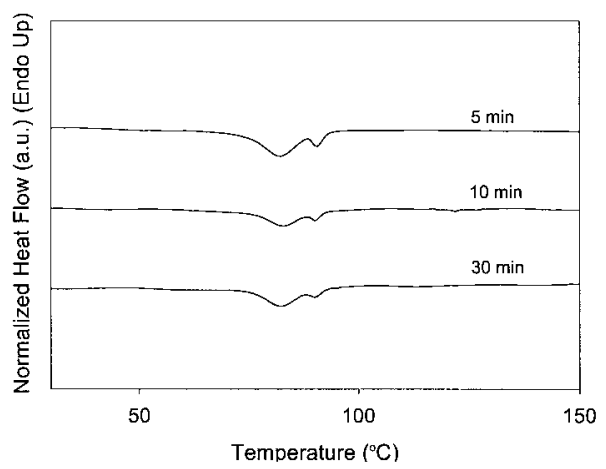

(b)

Figure 2 Effects of (a) repeated heating and cooling and (b) melt-annealing time on crystallization behavior of s-PP samples filled with 40 wt \% $1.9 \mu \mathrm{m}$, uncoated $\mathrm{CaCO}_{3}$ particles. 
exotherms. However, it did affect their breadth and height. Since many samples were used to obtain this set of data, it is apparent that the double crystallization behavior observed was not an artifact and that the results are highly reproducible.

To a first approximation, the occurrence of double crystallization behavior for s-PP samples loaded with high contents of $1.9 \mu \mathrm{m}$ uncoated $\mathrm{CaCO}_{3}$ particles may be a result of the self-nucleation effect, likely attributable to the residual s-PP crystallites entrapped along the rough surface of $\mathrm{CaCO}_{3}$ particles. In particular, the fact that the high-temperature crystallization peak occurred only in samples loaded with small $\mathrm{CaCO}_{3}$ particles is most likely due to the high surfacearea-to-volume ratio that these small particles exhibit, which could provide more rough sites on which s-PP crystallites become entrapped (in comparison with larger particles). Due to this entrapment, some of these crystallites may survive through the melting process, and, during subsequent cooling, they can act as predetermined nuclei to initiate crystallization.

If the above explanation is correct, it can be hypothesized that prolonged melting of s-PP samples loaded with high contents of $1.9 \mu \mathrm{m}$ uncoated $\mathrm{CaCO}_{3}$ particles should reduce the amount of residual s-PP crystallites entrapped along the rough surface of the particles. Furthermore, the entrapment of s-PP crystallites on the rough surface of the particles should be minimized when the $\mathrm{CaCO}_{3}$ surface is coated with a nonnucleating substance (hence reducing the probability for these entrapped crystallites to self-nucleate the s-PP melt during subsequent cooling). Regarding the former hypothesis, the results shown in Figure 2(b) indicate that prolonged melting of $40 \mathrm{wt} \% 1.9 \mu \mathrm{m}$ uncoated $\mathrm{CaCO}_{3}$-filled s-PP samples at 30 min clearly reduced the intensity of the high-temperature crystallization exotherm. Regarding the latter, the crystallization exotherms recorded for samples loaded with 40 wt \% $1.9 \mu \mathrm{m} \mathrm{CaCO}_{3}$ particles with various types of surface treatment (stearic acid coated and paraffincoated) exhibited only a single crystallization exotherm (results not shown). These observations suggest that the above explanation of the occurrence of the double crystallization behavior of s-PP samples loaded with high contents of $1.9 \mu \mathrm{m}$ uncoated $\mathrm{CaCO}_{3}$ particles are reasonable.

It should be noted at this point that the occurrence of double crystallization behavior was also reported for i-PP samples filled with $25 \mathrm{vol} \% 1.3 \mu \mathrm{m}$ uncoated $\mathrm{CaCO}_{3}$ (with the reported surface area of $5 \mathrm{~m}^{2} / \mathrm{g}$ ) by Pukánszky and Fekete. ${ }^{14}$ They attributed the occurrence of double crystallization behavior to aggregation. They also observed that this phenomenon depends very much on the specific surface area of the filler and on the composition, and that it only appears on samples with fillers of high surface area. We do believe that aggregation did occur to a greater extent

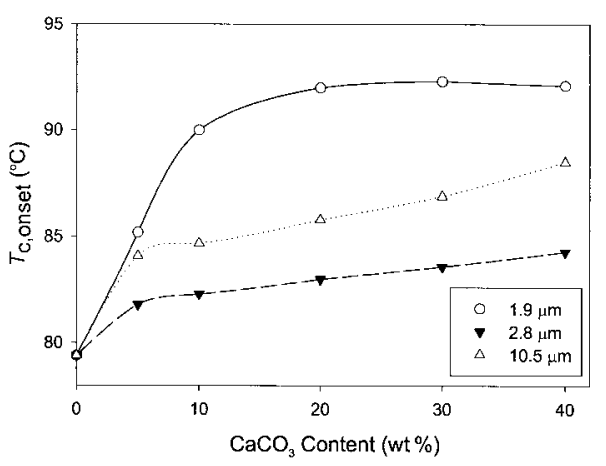

Figure 3 Crystallization (onset) temperature for neat s-PP and s-PP samples loaded with uncoated $\mathrm{CaCO}_{3}$ particles of various sizes as a function of $\mathrm{CaCO}_{3}$ content.

on $\mathrm{CaCO}_{3}$ of smaller particle size, but it is less likely that aggregation itself can be attributed to the occurrence of double crystallization behavior observed in both s-PP and i-PP systems (or any other system). Apart from the self-nucleation effect of entrapped crystallites, which is thought to be the most likely explanation for double crystallization behavior, other possible explanations should not be ruled out entirely. These include multiple crystal modifications and the differences in crystallization behavior of the polymer on different parts of the particle surface (i.e. different parts have different nucleating efficiency).

The crystallization (onset) temperature $T_{c, \text { onset }}$ values for neat s-PP and s-PP samples loaded with uncoated $\mathrm{CaCO}_{3}$ particles of various sizes as a function of $\mathrm{CaCO}_{3}$ content are reported in Figure 3, while Table II summarizes the non-isothermal crystallization results observed. According to Figure 3, it is apparent that the $T_{c, \text { onset }}$ value increased with increasing $\mathrm{CaCO}_{3}$ content, and, between samples loaded with 1.9 and 2.8 $\mu \mathrm{m}$ uncoated $\mathrm{CaCO}_{3}$ particles, the $T_{c \text {,onset }}$ value was found to increase with decreasing particle size (for a given filler loading). Interestingly, for samples loaded with $10.5 \mu \mathrm{m}$ uncoated $\mathrm{CaCO}_{3}$ grade, the $T_{c \text {,onset }}$ value was found to lie between those of samples loaded with 1.9 and $2.8 \mu \mathrm{m}$ uncoated $\mathrm{CaCO}_{3}$ particles, instead of falling below them as expected. It has been mentioned previously that the as-received $10.5 \mu \mathrm{m}$ uncoated $\mathrm{CaCO}_{3}$ grade contained not only calcite but dolomite as well. The enhancement of the nucleating efficiency of $\mathrm{CaCO}_{3}$ must be due to the presence of dolomite and the reason for this enhancement is not yet certain, since calcite and dolomite were found to have a similar unit cell (a trigonal unit cell) and very similar unit cell parameters. ${ }^{15,16}$ A possible explanation may rely on the relative characteristics of the surface free energy between calcite and s-PP crystallites and dolomite and s-PP crystallites.

According to Table II, the $T_{c \text {, onset }}$ values obtained for $1.9 \mu \mathrm{m}$ stearic acid-coated and $1.9 \mu \mathrm{m}$ paraffin-coated $\mathrm{CaCO}_{3}$-filled samples were lower than the value for 
TABLE II

Characteristics of Non-Isothermal Crystallization Observed for all of the Samples Studied

\begin{tabular}{|c|c|c|c|c|c|}
\hline \multirow[b]{2}{*}{ Material } & \multirow[b]{2}{*}{$\begin{array}{c}\text { Content } \\
\text { (wt \%) }\end{array}$} & \multicolumn{4}{|c|}{ Crystallization Characteristics } \\
\hline & & $\begin{array}{c}T_{c, o n s e t} \\
\left({ }^{\circ} \mathrm{C}\right)\end{array}$ & $\begin{array}{c}T_{c l} \\
\left({ }^{\circ} \mathrm{C}\right)\end{array}$ & $\begin{array}{l}T_{c h} \\
\left({ }^{\circ} \mathrm{C}\right)\end{array}$ & $\begin{array}{r}\Delta H_{c} \\
(\mathrm{~J} / \mathrm{g})\end{array}$ \\
\hline Neat s-PP & 0 & 79.4 & 74.4 & - & 33.5 \\
\hline \multirow[t]{5}{*}{$1.9 \mu \mathrm{m}$-Uncoated s-PP } & 5 & 85.2 & 79.9 & - & 33.5 \\
\hline & 10 & 90.0 & 80.8 & - & 34.8 \\
\hline & 20 & 92.0 & 81.2 & 89.8 & 32.0 \\
\hline & 30 & 92.3 & 81.9 & 89.9 & 24.4 \\
\hline & 40 & 92.1 & 81.5 & 90.5 & 19.1 \\
\hline \multirow[t]{5}{*}{$2.8 \mu \mathrm{m}$-Uncoated s-PP } & 5 & 81.8 & 76.8 & - & 28.4 \\
\hline & 10 & 82.3 & 77.6 & - & 26.6 \\
\hline & 20 & 83.0 & 78.2 & - & 16.8 \\
\hline & 30 & 83.6 & 79.0 & - & 17.6 \\
\hline & 40 & 84.3 & 79.4 & - & 10.1 \\
\hline \multirow[t]{5}{*}{$10.5 \mu \mathrm{m}$-Uncoated s-PP } & 5 & 84.1 & 79.1 & - & 30.5 \\
\hline & 10 & 84.7 & 79.6 & - & 27.1 \\
\hline & 20 & 85.8 & 80.5 & - & 29.1 \\
\hline & 30 & 86.9 & 81.3 & - & 22.3 \\
\hline & 40 & 88.5 & 81.9 & - & 21.9 \\
\hline \multirow[t]{5}{*}{$1.9 \mu \mathrm{m}$-Stearic acid-coated s-PP } & 5 & 81.7 & 76.7 & - & 28.6 \\
\hline & 10 & 82.4 & 77.3 & - & 29.7 \\
\hline & 20 & 83.2 & 78.3 & - & 24.2 \\
\hline & 30 & 84.4 & 79.1 & - & 28.4 \\
\hline & 40 & 84.8 & 79.5 & - & 23.8 \\
\hline \multirow[t]{5}{*}{$1.9 \mu \mathrm{m}$-Paraffin-coated s-PP } & 5 & 81.4 & 76.2 & - & 29.1 \\
\hline & 10 & 81.7 & 76.7 & - & 28.8 \\
\hline & 20 & 81.9 & 77.3 & - & 28.4 \\
\hline & 30 & 82.7 & 77.8 & - & 24.6 \\
\hline & 40 & 83.2 & 78.4 & - & 19.8 \\
\hline
\end{tabular}

$1.9 \mu \mathrm{m}$ uncoated $\mathrm{CaCO}_{3}$-filled samples at the same filler loading. Clearly, the nucleating efficiency of $\mathrm{CaCO}_{3}$ was reduced by such surface treatments. This is in a good agreement with results obtained by Rybnikar, ${ }^{17}$ in which he reports that the nucleating efficiency of $\mathrm{CaCO}_{3}$ could be increased or decreased by a suitable surface treatment. He also found that stearic acid coating on $\mathrm{CaCO}_{3}$ has an adverse effect on the nucleating efficiency of $\mathrm{CaCO}_{3}$ in i-PP. Referring to the aforementioned findings, the coating of $\mathrm{CaCO}_{3}$ surface reduces the tendency for s-PP molecules to be partially absorbed, thus reducing the total amount of entrapped s-PP crystallites, which decreases in the probability of their initiating crystallization. At this point, it is worthy to note that nucleating efficiency of $\mathrm{CaCO}_{3}$ depends very much on its purity, surface properties (i.e. specific surface area and type of surface modification), and average particle size.

Crystallization studies are incomplete without information about subsequent melting behavior. Figure 4 shows the subsequent melting endotherms for neat and $1.9 \mu \mathrm{m}$ uncoated $\mathrm{CaCO}_{3}$-filled s-PP samples at various filler contents (recorded at a heating rate of $20^{\circ} \mathrm{C} / \mathrm{min}$ ). Under the crystallization conditions studied, some samples with single crystallization peaks showed double melting endotherms in their heating scans, while others with double crystallization peaks showed three melting endotherms. The occurrence of double melting endotherms in s-PP is fully explained in an earlier report, ${ }^{18}$ in which the low-temperature melting endotherm (the peak temperature of which denotes $T_{m l}$ ) corresponds to the melting of primary crystallites formed (at $T_{c l}$ ), and the high-temperature melting peak (the peak temperature of which denotes $T_{m h}$ ) corresponds to the melting of re-crystallized crystallites formed during a heating scan.

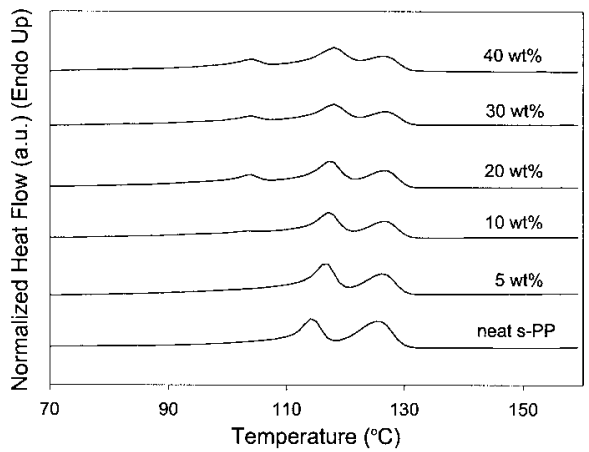

Figure 4 Subsequent melting endotherms for neat s-PP and $1.9 \mu \mathrm{m}$, uncoated $\mathrm{CaCO}_{3}$-filled s-PP samples at various filler contents (recorded at a heating rate of $20^{\circ} \mathrm{C} / \mathrm{min}$ ). 
TABLE III

Characteristics of Subsequent Melting Observed for All Samples Studied Including WAXD Degree of Crystallinity

\begin{tabular}{|c|c|c|c|c|c|c|c|}
\hline \multirow[b]{2}{*}{ Material } & \multirow[b]{2}{*}{$\begin{array}{c}\text { Content } \\
\text { (wt \%) }\end{array}$} & \multicolumn{6}{|c|}{ Melting characteristics } \\
\hline & & $\begin{array}{c}T_{m \text {,onset }} \\
\left({ }^{\circ} \mathrm{C}\right)\end{array}$ & $\begin{array}{l}T_{m l 2} \\
\left({ }^{\circ} \mathrm{C}\right)\end{array}$ & $\begin{array}{l}T_{m l} \\
\left({ }^{\circ} \mathrm{C}\right)\end{array}$ & $\begin{array}{l}T_{m n} \\
\left({ }^{\circ} \mathrm{C}\right)\end{array}$ & $\begin{array}{l}\Delta H_{m} \\
(\mathrm{~J} / \mathrm{g})\end{array}$ & $\begin{array}{c}\chi_{(\%)}^{\text {WAXD }} \\
(\%)\end{array}$ \\
\hline \multirow[t]{3}{*}{ Neat s-PP } & 0 & 110.0 & - & 114.4 & 125.5 & 33.8 & 16.2 \\
\hline & 5 & 112.0 & - & 116.7 & 126.4 & 34.0 & 13.7 \\
\hline & 10 & 112.2 & - & 117.2 & 126.9 & 33.6 & - \\
\hline \multirow[t]{5}{*}{$1.9 \mu \mathrm{m}$-Uncoated s-PP } & 20 & 112.1 & 103.7 & 117.5 & 126.9 & 31.4 & 12.5 \\
\hline & 30 & 112.0 & 104.0 & 118.0 & 127.1 & 25.9 & - \\
\hline & 40 & 111.5 & 104.1 & 118.0 & 127.0 & 22.0 & 9.7 \\
\hline & 5 & 111.0 & - & 115.4 & 125.9 & 33.5 & 13.1 \\
\hline & 10 & 111.2 & - & 115.5 & 125.8 & 32.1 & - \\
\hline \multirow[t]{5}{*}{$2.8 \mu \mathrm{m}$-Uncoated s-PP } & 20 & 111.5 & - & 116.1 & 126.3 & 33.8 & 11.4 \\
\hline & 30 & 111.5 & - & 116.0 & 126.0 & 28.7 & - \\
\hline & 40 & 111.4 & - & 116.1 & 126.0 & 26.8 & 9.8 \\
\hline & 5 & 112.2 & - & 116.7 & 126.8 & 36.2 & 13.4 \\
\hline & 10 & 112.1 & - & 116.7 & 126.6 & 32.9 & - \\
\hline \multirow[t]{5}{*}{$10.5 \mu \mathrm{m}$-Uncoated s-PP } & 20 & 112.2 & - & 117.0 & 126.6 & 28.5 & 13.0 \\
\hline & 30 & 111.9 & - & 117.4 & 126.6 & 27.9 & - \\
\hline & 40 & 111.6 & - & 117.5 & 126.4 & 23.9 & 9.6 \\
\hline & 5 & 111.0 & - & 115.5 & 126.0 & 33.4 & 11.7 \\
\hline & 10 & 111.3 & - & 115.8 & 126.1 & 32.7 & - \\
\hline \multirow[t]{5}{*}{$1.9 \mu \mathrm{m}$-Stearic acid-coated s-PP } & 20 & 111.7 & - & 115.8 & 125.6 & 27.6 & 11.3 \\
\hline & 30 & 112.1 & - & 116.1 & 126.3 & 23.0 & - \\
\hline & 40 & 112.1 & - & 116.4 & 126.3 & 19.7 & 9.9 \\
\hline & 5 & 110.5 & - & 114.8 & 125.6 & 31.2 & 14.2 \\
\hline & 10 & 110.9 & - & 115.1 & 125.6 & 30.2 & - \\
\hline \multirow[t]{3}{*}{$1.9 \mu \mathrm{m}$-Paraffin-coated s-PP } & 20 & 111.1 & - & 115.5 & 125.8 & 29.9 & 13.0 \\
\hline & 30 & 111.2 & - & 115.6 & 125.8 & 26.3 & - \\
\hline & 40 & 111.4 & - & 115.7 & 125.8 & 22.1 & 12.4 \\
\hline
\end{tabular}

According to Figure 4, another low-temperature melt endotherm (the peak temperature of which denotes $T_{m l 2}$ ) observed on subsequent melt endotherms of s-PP loaded with high contents of $1.9 \mu \mathrm{m}$ uncoated $\mathrm{CaCO}_{3}$ particles (approx. 20-40 wt \%) must correspond to the high-temperature crystallization peak observed on crystallization exotherms (see Fig. 1). This is rather surprising since the comparatively low value of $T_{m l 2}$ suggests low stability of the crystallites, despite their being formed at relatively high temperatures $\left(T_{c h}\right)$. The reason for this unexpected behavior is not certain at this point. When considering the resulting $T_{m l}$ values for s-PP samples loaded with uncoated $\mathrm{CaCO}_{3}$ particles of various sizes as a function of $\mathrm{CaCO}_{3}$ content (not shown), it is evident that the results obtained agreed particularly well with the crystallization results (see Fig. 3) in that the $T_{m l}$ value increased with increasing $\mathrm{CaCO}_{3}$ content. Also, between samples loaded with 1.9 and $2.8 \mu \mathrm{m}$ uncoated $\mathrm{CaCO}_{3}$ particles, the $T_{m l}$ value was found to increase with decreasing particle size, and that of the samples loaded with $10.5 \mu \mathrm{m}$ uncoated $\mathrm{CaCO}_{3}$ fell essentially in between. Table III summarizes the results regarding subsequent melting behavior obtained for all of the samples studied.

\section{Crystal structure and crystallinity}

In order to observe the crystal structure and the resulting apparent degree of crystallinity of the various s-PP $/ \mathrm{CaCO}_{3}$ compounds investigated, a WAXD technique was utilized. Figure 5(a) shows the WAXD patterns for neat and $1.9 \mu \mathrm{m}$ uncoated $\mathrm{CaCO}_{3}$-filled s-PP samples at various filler contents. Each sample was prepared in the DSC cell at a cooling rate of $10^{\circ} \mathrm{C} / \mathrm{min}$. For the neat s-PP sample, the characteristic $\mathrm{X}$-ray peaks were observed at the scattering angles $2 \theta$ of about $12.2,15.9,20.6$ and $24.6^{\circ}$, corresponding to the limit-disordered form $\mathrm{I}^{19-21}$ (according to the most recent nomenclature suggested by De Rosa et al. ${ }^{22}$ ), which has an orthorhombic unit cell with axes $a=14.5$ $\AA, b=5.6 \AA$, and $c=7.4 \AA$. According to this unit cell, the characteristic $X$-ray peaks should be observed at angles $2 \theta$ of about 12.2, 15.8, 20.8 and $24.5^{\circ}$, corresponding respectively to the reflection planes of (200), (010), (111), and (400). Comparison to isothermally crystallized neat s-PP samples reported earlier ${ }^{23}$ suggests that the reflection onto (010) planes for nonisothermally crystallized neat s-PP samples (in this study) was much less pronounced.

In Figure 5(a), the effect of $\mathrm{CaCO}_{3}$ content on the diffractograms of neat s-PP and s-PP samples filled 

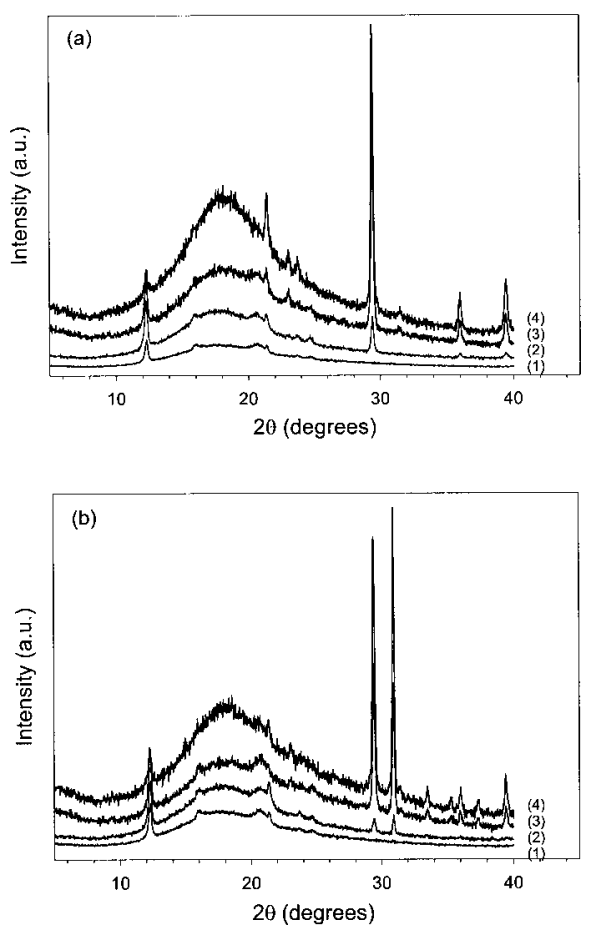

Figure 5 WAXD patterns for (a) neat s-PP and $1.9 \mu \mathrm{m}$, uncoated $\mathrm{CaCO}_{3}$-filled s-PP samples and (b) neat s-PP and $10.5 \mu \mathrm{m}$, uncoated $\mathrm{CaCO}_{3}$-filled s-PP samples at various filler contents: (1) $0 \mathrm{wt} \%$, (2) $5 \mathrm{wt} \%$, (3) $20 \mathrm{wt} \%$, and (4) 40 wt $\%$.

with $1.9 \mu \mathrm{m}$ uncoated $\mathrm{CaCO}_{3}$ particles is obvious. As $\mathrm{CaCO}_{3}$ content increases, the intensities of the characteristic X-ray peaks of s-PP crystallites becomes less pronounced, with the characteristic peaks at an angle $2 \theta$ of about $15.9^{\circ}$ disappearing when $\mathrm{CaCO}_{3}$ content is greater than about $5 \mathrm{wt} \%$ and those at angles $2 \theta$ of about 20.6 and $24.6^{\circ}$ disappearing altogether when $\mathrm{CaCO}_{3}$ content is greater than about $20 \mathrm{wt} \%$. On the other hand, the major characteristic peaks of calcite at angles $2 \theta$ of about 29.0 and $39.4^{\circ}$ are evident when $\mathrm{CaCO}_{3}$ content is greater than $5 \mathrm{wt} \%$ and become more pronounced and intensified with increasing $\mathrm{CaCO}_{3}$ content. With the exception of s-PP samples loaded with $10.5 \mu \mathrm{m}$ uncoated $\mathrm{CaCO}_{3}$ particles, similar behavior is observed for s-PP samples filled with $2.8 \mu \mathrm{m}$ uncoated $\mathrm{CaCO}_{3}$ particles.

Figure 5(b) shows the WAXD diffractograms of neat s-PP and s-PP samples filled with $10.5 \mu \mathrm{m}$ uncoated $\mathrm{CaCO}_{3}$ particles. It is clear that, with increasing $\mathrm{CaCO}_{3}$ content, the intensities of the characteristic X-ray peaks of s-PP crystallites become less pronounced, with the characteristic peaks at angles $2 \theta$ of about 15.9, 20.6 and $24.6^{\circ}$ disappearing altogether when $\mathrm{CaCO}_{3}$ content is greater than about $20 \mathrm{wt} \%$. Similarly, major characteristic peaks of calcite at angles $2 \theta$ of about 29.0 and $39.4^{\circ}$ were apparent when $\mathrm{CaCO}_{3}$ content was greater than $5 \mathrm{wt} \%$ and became more pronounced and intensified with increasing $\mathrm{CaCO}_{3}$ content. An additional characteristic X-ray peak at an angle $2 \theta$ of about $30.9^{\circ}$, which is attributed to dolomite, is also evident when $\mathrm{CaCO}_{3}$ content is greater than 5 wt \% and becomes more pronounced and intensified with increasing $\mathrm{CaCO}_{3}$ content.

The results shown in Figures 5(a,b) suggest that the presence of $\mathrm{CaCO}_{3}$ particles does not alter the crystal structure of the crystallizing s-PP in the matrix. It does, however, affect the apparent degree of crystallinity, $\chi^{\mathrm{WAXD}}$, of the s-PP matrix. By referring to the relative ratio of the integrated intensities under the crystalline peaks $A_{c}$ to the integrated total intensity $A_{t}$ $\left(A_{t}=A_{c}+A_{a}\right.$, where $A_{a}$ is the integrated intensity under the amorphous halo), the following equation can be derived:

$$
\chi^{\mathrm{WAXD}}=\frac{A_{c}}{A_{c}+A_{a}} \in[0,1],
$$

It is qualitatively obvious that the WAXD degree of crystallinity $\chi^{\mathrm{WAXD}}$ decreases with increasing $\mathrm{CaCO}_{3}$ content. It should be noted that contributions from the crystalline peaks of calcite and dolomite were excluded from the calculation. The observed $\chi^{\mathrm{WAXD}}$ values for all of the samples studied are summarized in Table III.

\section{Mechanical properties}

Tensile properties

According to Figure 6(a), the tensile strength values for neat s-PP and s-PP samples filled with uncoated $\mathrm{CaCO}_{3}$ particles of various sizes were found to decrease gradually with increasing $\mathrm{CaCO}_{3}$ content (approx. 18.5-13 $\mathrm{MPa}$ ), with the exception of samples filled with very low contents of $1.9 \mu \mathrm{m}$ uncoated $\mathrm{CaCO}_{3}$ (less than $\approx 5 \mathrm{wt} \%$ ) which seem to increase to a maximum and then decrease. The decrease of tensile strength is probably due to the poor interfacial adhesion between the $\mathrm{CaCO}_{3}$ surface and the s-PP matrix, resulting in poor stress transfer across the interface. The fact that the results were not affected by variation in the particle size suggests that the tensile strength is controlled primarily by the filler content rather than by its size. When compared to the results obtained for samples loaded with $1.9 \mu \mathrm{m}$ uncoated $\mathrm{CaCO}_{3}$ particles, both stearic acid and paraffin coating on the $\mathrm{CaCO}_{3}$ particles resulted in the reduction of the tensile strength of the s-PP/ $\mathrm{CaCO}_{3}$ compounds [see Fig. 6(b)]. On the other hand, the Young's modulus was found to increase with increasing $\mathrm{CaCO}_{3}$ content (approx. 440-700 MPa), as shown in Figure 7(a). This may be due to the stiffening effect, a direct result of the presence of the rigid dispersed phase of $\mathrm{CaCO}_{3}$ particles within the s-PP matrix, and the increase in the number of crystallites nucleated by $\mathrm{CaCO}_{3}$. As compared to the results obtained for samples loaded with $1.9 \mu \mathrm{m}$ uncoated $\mathrm{CaCO}_{3}$ particles, both stearic acid and paraffin 

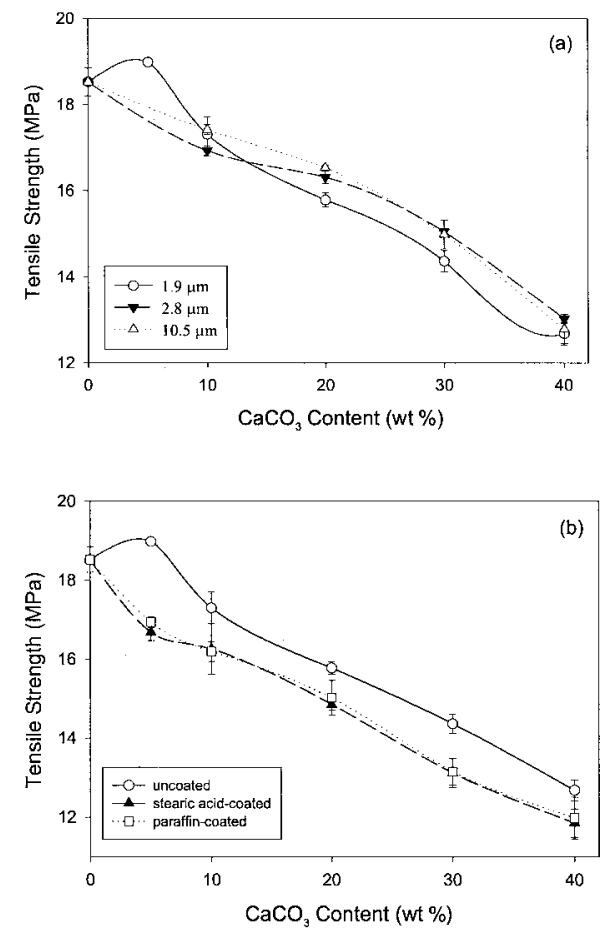

Figure 6 Tensile strength of neat s-PP and s-PP/ $\mathrm{CaCO}_{3}$ compounds as a function of $\mathrm{CaCO}_{3}$ content exhibiting (a) the effect of varying particle size and (b) the effect of surface coating.

coating on the $\mathrm{CaCO}_{3}$ particles resulted in the reduction of the Young's modulus [see Fig. 7(b)].

The influence of glass beads and talcum on the mechanical properties of s-PP was reported by Stricker et al. ${ }^{11}$ The s-PP resins used in their work had the following molecular characteristics: for SPH-4 resin, $M_{n}=106,000 \mathrm{Da}, M_{w} / M_{n}=1.7,(\% r r)=82.2 \%$; and, for SPH-40 resin, $M_{n}=80,000 \mathrm{Da}, M_{w} / M_{n}=1.7$, and $(\% r r)=91.1 \%$. The glass beads had an average diameter of $5 \mu \mathrm{m}$ and were coated with $0.02 \mathrm{wt} \%$ aminopropyltrimethoxysilane, and the talcum had an average diameter of $10 \mu \mathrm{m}$. They found that the Young's moduli of both functionalized glass beadfilled and talcum-filled s-PP increased with increasing filler volume content $(0-30 \mathrm{vol} \%)$, with those for glass bead-filled samples (for both resins) increasing from about 375 to $800 \mathrm{MPa}$ and those for talcum-filled samples (for SPH-4 resin) increasing from about 370 to 1,250 MPa (see Fig. 1 in ref. 11). When simultaneously comparing filler loading (at approx. 18 vol \% or $40 \mathrm{wt}$ $\%$ for $\mathrm{CaCO}_{3}$-filled s-PP), the Young's modulus of $\mathrm{CaCO}_{3}$-filled s-PP (approx. $700 \mathrm{MPa}$ ) was found to be greater than that of glass bead-filled s-PP (approx. 620 $\mathrm{MPa})$, while it was lower than that of talcum-filled s-PP (approx. $900 \mathrm{MPa}$ ).

\section{Impact resistance}

The Izod impact resistance of neat s-PP and s-PP samples filled with uncoated $\mathrm{CaCO}_{3}$ particles of various sizes was, in general, found to decrease with increasing particle size and $\mathrm{CaCO}_{3}$ content [see Fig. 8(a)]. Interestingly, the samples filled with low contents of $1.9 \mu \mathrm{m}$ uncoated $\mathrm{CaCO}_{3}$ particles (< approx. $10 \mathrm{wt} \%$ ) showed a maximum Izod impact resistance value. The increase in the impact resistance at low filler contents may be attributed to the formation of smaller crystallites, as well as to the ability to absorb more energy by the increased portion of the amorphous phase. ${ }^{24}$ The main reason for the decrease in impact resistance of s-PP $/ \mathrm{CaCO}_{3}$ compounds with increasing $\mathrm{CaCO}_{3}$ content is likely the poor adhesion at the s-PP/ $\mathrm{CaCO}_{3}$ interface. Upon failure, cracks tend to preferentially propagate along the weaker interfacial region rather than through the polymer matrix, because of the higher resistance to propagation within the polymer matrix. ${ }^{25}$

The effect of surface modification of $1.9 \mu \mathrm{m} \mathrm{CaCO}$ particles on the Izod impact resistance of filled s-PP samples is shown in Figure 8(b). Generally, the impact resistance of samples filled with surface-modified $\mathrm{CaCO}_{3}$ particles was better than that of samples filled with unmodified $\mathrm{CaCO}_{3}$. Interestingly, samples loaded with paraffin-coated $\mathrm{CaCO}_{3}$ particles exhibited much greater impact resistance than those with uncoated and stearic acid-coated $\mathrm{CaCO}_{3}$ ones. Riley et al. ${ }^{26}$ reported that, for i-PP $/ \mathrm{CaCO}_{3}$ compounds, surface coating on $\mathrm{CaCO}_{3}$ particles with stearic acid
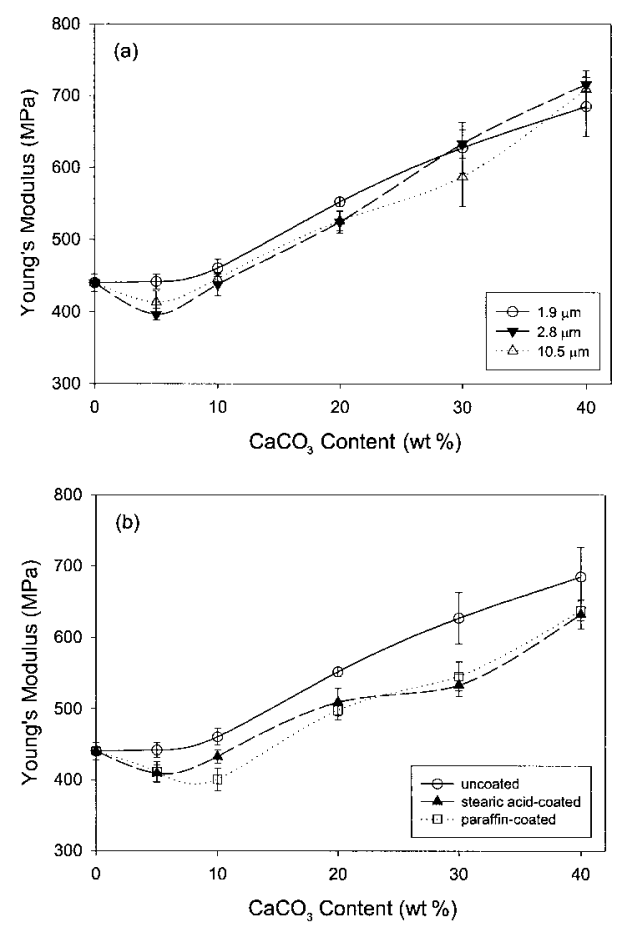

Figure 7 Young's modulus of neat s-PP and s- $\mathrm{PP} / \mathrm{CaCO}_{3}$ compounds as a function of $\mathrm{CaCO}_{3}$ content exhibiting (a) the effect of varying particle size and (b) the effect of surface coating. 

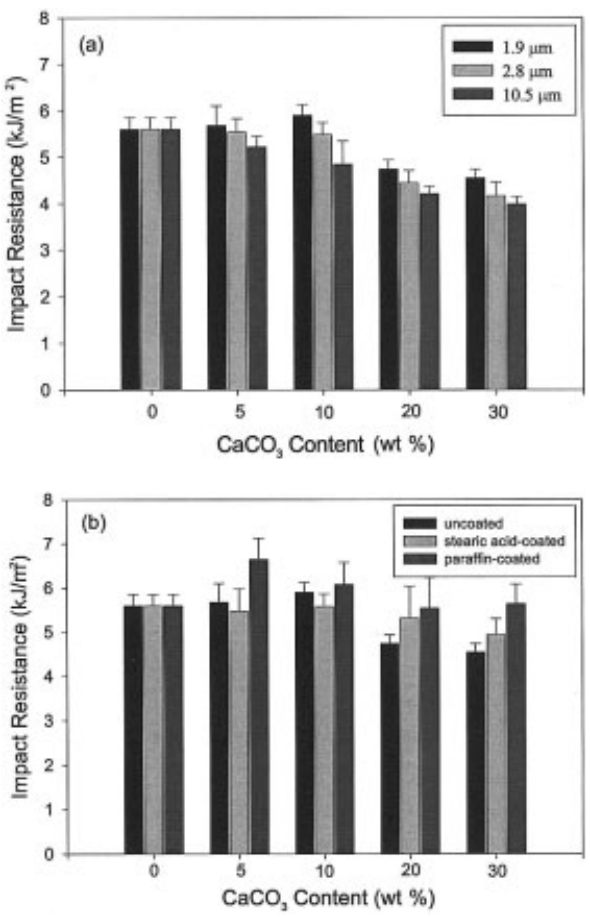

Figure 8 Izod impact resistance of neat s-PP and s-PP/ $\mathrm{CaCO}_{3}$ compounds as a function of $\mathrm{CaCO}_{3}$ content exhibiting (a) the effect of varying particle size and (b) the effect of surface coating.

helped the dispersion of $\mathrm{CaCO}_{3}$ particles in the i-PP matrix. Better dispersion means a larger number of discrete filler particles to help retard crack propagation (viz. a larger effective area along the s-PP/ $/ \mathrm{CaCO}_{3}$ interface to help absorb the impact energy).

\section{Morphology of fracture surface}

In order to verify the poor interfacial adhesion at the s-PP/ $\mathrm{CaCO}_{3}$ interface and determine whether stearic acid and paraffin coating of $\mathrm{CaCO}_{3}$ particles really help its dispersion in the s-PP matrix, SEM was used to observe the fracture surfaces of selected fracture samples obtained from the impact testing.

SEM micrographs of the fractured surfaces of selected impact test specimens for s-PP filled with $20 \mathrm{wt}$ $\%$ 1.9, 2.8, and $10.5 \mu \mathrm{m}$ uncoated $\mathrm{CaCO}_{3}$ particles are shown in Figures 9(a-c), respectively; while those for s-PP filled with $40 \mathrm{wt} \% 1.9,2.8$, and $10.5 \mu \mathrm{m}$ uncoated $\mathrm{CaCO}_{3}$ samples are shown in Figures $9(\mathrm{~d}-\mathrm{f})$, respectively. According to these micrographs, the dispersion of uncoated $\mathrm{CaCO}_{3}$ particles appears to be rather uniform. However, for specimens loaded with $40 \mathrm{wt} \% 1.9$ and $2.8 \mu \mathrm{m}$ uncoated $\mathrm{CaCO}_{3}$ particles [see Fig. 9(d, e)], large agglomerates are evident. This is mainly due to the fact that the small particles have large surface area, causing them to aggregate fairly easily, especially at high filler contents. ${ }^{14}$ Careful examination of all mi- crographs suggests that $\mathrm{CaCO}_{3}$ particles are pulled out of the s-PP matrix rather easy (as evidenced by the smooth surface of the pull-out sites). This clearly indicates that the adhesion between $\mathrm{CaCO}_{3}$ particles and the s-PP matrix is poor.

The effects of stearic acid and paraffin coating of $\mathrm{CaCO}_{3}$ particles on their dispersion within the s-PP matrix were also investigated. Figures $9(a)$ and 10(a, b) respectively show SEM micrographs of the fractured surfaces of selected impact test specimens for s-PP filled with $20 \mathrm{wt} \%$ uncoated, stearic acid-coated and paraffin-coated $1.9 \mu \mathrm{m} \mathrm{CaCO}{ }_{3}$ particles. Figures 9(d) and $10(\mathrm{c}, \mathrm{d})$ respectively show those for s-PP filled with $40 \mathrm{wt} \%$ uncoated, stearic acid-coated and paraffin-coated $1.9 \mu \mathrm{m} \mathrm{CaCO}$ particles. For the $\mathrm{CaCO}_{3}$ contents studied, $\mathrm{CaCO}_{3}$ particles were well dispersed without appreciable agglomeration when their surfaces were coated with stearic acid and paraffin. It is also obvious from these micrographs that the adhesion between the coated $\mathrm{CaCO}_{3}$ particles and the s-PP matrix was not improved, suggesting that surface modification of $\mathrm{CaCO}_{3}$ particles with stearic acid and paraffin only helped the dispersion of the particles within the matrix.

\section{Shear viscosity}

The processability of s-PP/ $\mathrm{CaCO}_{3}$ compounds can be assessed by measuring their steady-state shear viscos-
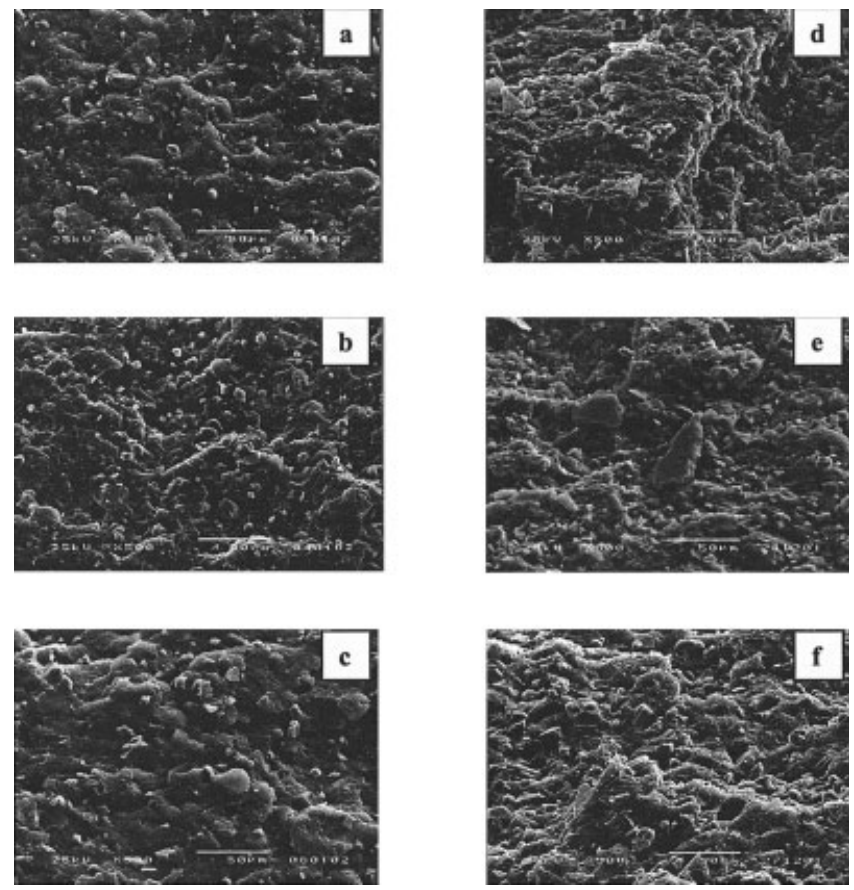

Figure 9 SEM micrographs of fractured surfaces of selected impact test specimens for s-PP filled with (a) 1.9, (b) 2.8, and (c) $10.5 \mu \mathrm{m}$, uncoated $\mathrm{CaCO}_{3}$ particles at $20 \mathrm{wt} \%$ and (d) 1.9 , (e) 2.8 , and (f) $10.5 \mu \mathrm{m}$, uncoated $\mathrm{CaCO}_{3}$ samples at $40 \mathrm{wt} \%$. 

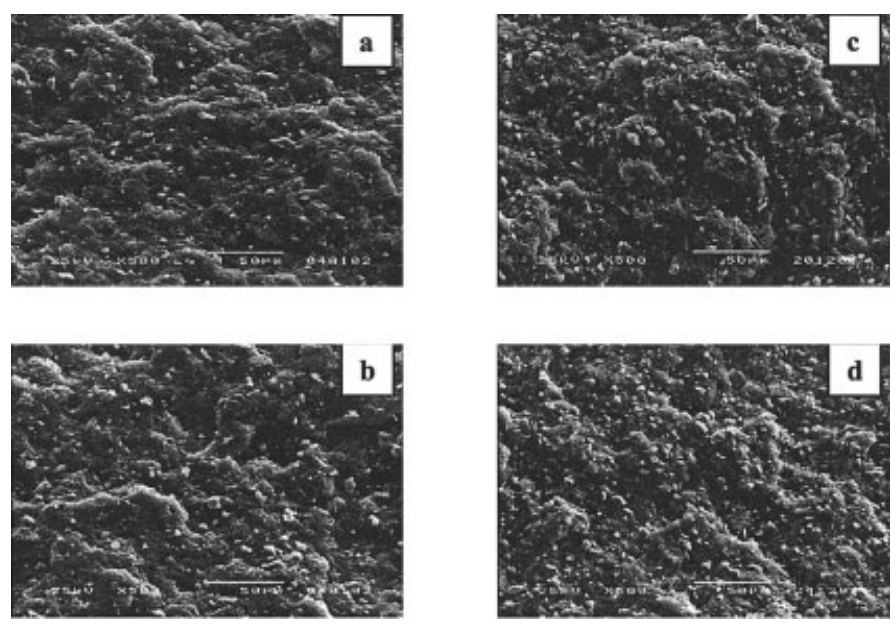

Figure 10 SEM micrographs of fractured surfaces of selected impact test specimens for s-PP filled with (a) stearic acid-coated and (b) paraffin-coated $1.9 \mu \mathrm{m} \mathrm{CaCO}_{3}$ particles at $20 \mathrm{wt} \%$ and (c) stearic acid-coated and (d) paraffin-coated $1.9 \mu \mathrm{m} \mathrm{CaCO}$ samples at $40 \mathrm{wt} \%$.

ity. The steady-state shear viscosity of s-PP/ $\mathrm{CaCO}_{3}$ compounds was measured over a shear-rate range of 0.25 to $3,000 \mathrm{~s}^{-1}$ at a fixed temperature of $200^{\circ} \mathrm{C}$. Two different types of rheometers were used: a parallelplate rheometer (to cover a shear-rate range of 0.25 to $25 \mathrm{~s}^{-1}$ and a capillary rheometer (to cover a shear-rate range of 50 to $3,000 \mathrm{~s}^{-1}$ ). The dependence of the steady-state shear viscosity of s-PP/ $\mathrm{CaCO}_{3}$ compounds on content, particle size, and type of surface modification of $\mathrm{CaCO}_{3}$ particles was investigated.

The steady-state shear viscosity of neat and $1.9 \mu \mathrm{m}$ uncoated $\mathrm{CaCO}_{3}$-filled s-PP samples of various filler contents as a function of shear rate is shown in Figure 11. Apparently, the neat and $1.9 \mu \mathrm{m}$ uncoated $\mathrm{CaCO}_{3}-$ filled s-PP samples of "low" filler loadings (approx. 5-20 wt \%) exhibited typical shear thinning behavior, with a plateau region observed at low shear rates $(<$ approx. $1 \mathrm{~s}^{-1}$ ) and a shear thinning region at high shear rates ( $>$ approx. $1 \mathrm{~s}^{-1}$ ). At high filler loadings $(>$

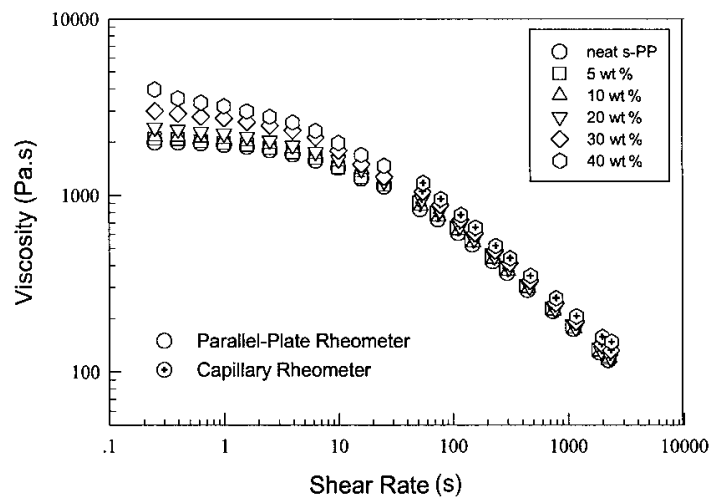

Figure 11 Steady-state shear viscosity of neat s-PP and 1.9 $\mu \mathrm{m}$, uncoated $\mathrm{CaCO}_{3}$-filled s-PP samples of various filler contents as a function of shear rate. approx. $20 \mathrm{wt} \%$ ), however, the compounds exhibited shear thinning behavior as well, but without the presence of a plateau region at low shear rates, and the viscosity values were always non-Newtonian and became increasingly nonlinear and unbounded with decreasing shear rate. Such an unbounded shear viscosity represents yielding as predicted by most viscoelastic models in which the apparent viscosity approaches infinity at vanishing shear rates, a direct result of the presence of yield stress below which there is no flow. ${ }^{27,28}$ The other compounds filled with larger par-
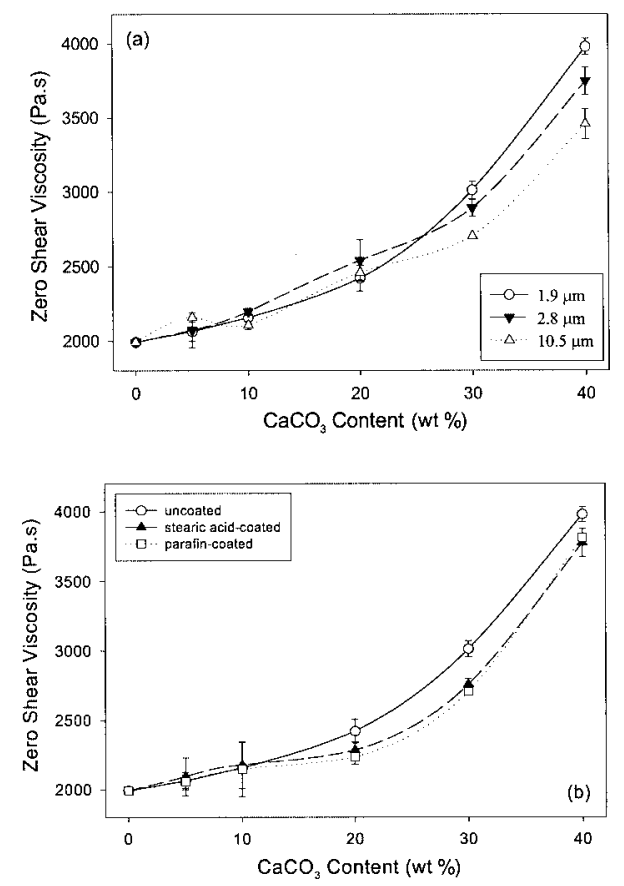

Figure 12 Zero shear viscosity of neat s-PP and s-PP/ $\mathrm{CaCO}_{3}$ compounds as a function of $\mathrm{CaCO}_{3}$ content. 
ticle sizes (2.8 and $10.5 \mu \mathrm{m}$ ) also exhibited similar behavior to that described above.

Figure 12(a) compares the zero shear viscosity values (taken as the viscosity values at a shear rate of approx. $0.25 \mathrm{~s}^{-1}$ ) of neat s-PP and s-PP/ $\mathrm{CaCO}_{3}$ samples filled with $\mathrm{CaCO}_{3}$ particles of various particle sizes as a function of $\mathrm{CaCO}_{3}$ content. Apparently, the zero shear viscosity values were found to increase monotonically with increasing filler loading. It should be noted that the enhancement of the shear viscosity due to the presence of non-interactive rigid particles in dilute suspensions was proposed long ago by Einstein, ${ }^{29,30}$ who pointed out that the enhancement of the shear viscosity is a result of increased energy dissipation due to the presence of the particles. In more concentrated systems, stronger interactions between filler particles give rise to much larger energy dissipation, resulting in much stronger viscosity enhancement. $^{31}$ This is exactly the reason for the profound increase in the zero shear viscosity values at high filler loadings observed for the s-PP $/ \mathrm{CaCO}_{3}$ compounds.

Another interesting observation from data shown in Figure 12(a) is that, among samples loaded with uncoated $\mathrm{CaCO}_{3}$ at high filler loadings (> approx. $20 \mathrm{wt}$ \%), $1.9 \mu \mathrm{m}$ uncoated $\mathrm{CaCO}_{3}$-filled s-PP samples exhibited the highest zero shear viscosity value. It is a known fact that the smaller the filler particles, the larger the surface area, giving rise to a greater possibility of the formation of inter-particular structure. As a result of the strong inter-particular interactions, the enhancement of the shear viscosity for the samples filled with these fine $\mathrm{CaCO}_{3}$ particles was apparent. However, when the surface of $\mathrm{CaCO}_{3}$ particles was coated with stearic acid and paraffin, inter-particular interactions were affected in an adverse manner, as evidenced by the reduction in the zero shear viscosity values at high filler loadings ( $>$ approx. $10 \mathrm{wt} \%$ ) [see Fig. 12(b)]. This is quite interesting, since SEM micrographs showed that the dispersion of $\mathrm{CaCO}_{3}$ particles within the s-PP matrix was enhanced by such surface modifications. This implies that, even though it is responsible for improving particulate dispersion, surface modifications of $\mathrm{CaCO}_{3}$ particles with stearic acid and paraffin reduce the inter-particular interactions as a result of the reduction of the effective area of the particles.

\section{CONCLUSIONS}

In this study, the effects of $\mathrm{CaCO}_{3}$ with varying particle sizes $(1.9,2.8$ and $10.5 \mu \mathrm{m})$, contents $(0-40 \mathrm{wt} \%)$, and types of surface modification (uncoated, stearic acid-coated, and paraffin-coated) on crystallization and melting behavior, mechanical properties (tensile and impact properties), and processability (steadystate shear viscosity) of s-PP $/ \mathrm{CaCO}_{3}$ compounds were investigated.
Non-isothermal crystallization studies revealed that incorporation of $\mathrm{CaCO}_{3}$ particles shifted the crystallization peak towards a higher temperature, but the increase in the crystallization peak only occurred very slightly with further increase in the $\mathrm{CaCO}_{3}$ content. Two types of crystallization exotherm were observed: the single-peak type and the double-peak type. The double-peak type was only found for s-PP samples loaded with "high" contents of $1.9 \mu \mathrm{m}$ uncoated $\mathrm{CaCO}_{3}$ particles, which was postulated to be a result of the self-nucleation effect of residual s-PP crystallites entrapped along the rough surface of $\mathrm{CaCO}_{3}$ particles. When considering the effect of $\mathrm{CaCO}_{3}$ particle size on the crystallization behavior of s-PP/ $\mathrm{CaCO}_{3} \mathrm{com}-$ pounds, it was found that the crystallization (onset) temperature increased with increasing $\mathrm{CaCO}_{3}$ content and decreasing particle size. This general statement does not hold true, however, for samples loaded with $10.5 \mu \mathrm{m}$ uncoated $\mathrm{CaCO}_{3}$ particles, most likely due to the presence of dolomite. Surface coating of $\mathrm{CaCO}_{3}$ particles with stearic acid and paraffin reduced the nucleating ability of the particles. WAXD results suggested that the incorporation of $\mathrm{CaCO}_{3}$ did not affect the crystal structure of the crystallizing s-PP in the matrix, but it adversely affected the apparent degree of crystallinity.

In general, the tensile strength of s-PP $/ \mathrm{CaCO}_{3} \mathrm{com}-$ pounds was found to decrease gradually with increasing $\mathrm{CaCO}_{3}$ content, most likely due to the poor interfacial adhesion between the $\mathrm{CaCO}_{3}$ surface and the s-PP matrix.The average size of $\mathrm{CaCO}_{3}$ particles did not appear to affect the tensile strength noticeably. On the other hand, the Young's modulus was found to increase with increasing $\mathrm{CaCO}_{3}$ content, most likely a result of the stiffening effect contributed by the presence of rigid particles. Both stearic acid and paraffin coating on the $\mathrm{CaCO}_{3}$ particles resulted in the reduction of both the tensile strength and the Young's modulus. Similarly, the Izod impact resistance of samples loaded with uncoated $\mathrm{CaCO}_{3}$ particles of various sizes was, in general, found to decrease with increasing particle size and content, most likely due to the poor interfacial adhesion between the s- $\mathrm{PP} / \mathrm{CaCO}_{3}$ interface. Both stearic acid and paraffin coating on the $\mathrm{CaCO}_{3}$ particles helped to improve the Izod impact resistance, a result of the improved dispersion within the s-PP matrix.

Lastly, the inclusion of $\mathrm{CaCO}_{3}$ particles to a large extent affected the shear viscosity of s-PP/ $\mathrm{CaCO}_{3}$ compounds. The zero shear viscosity was found to increase monotonically with increasing $\mathrm{CaCO}_{3}$ content, with the samples loaded with $1.9 \mu \mathrm{m}$ uncoated $\mathrm{CaCO}_{3}$ particles exhibiting the highest value, possibly due to the formation of inter-particular structures of these small, rigid particles. The zero shear viscosity was reduced when the surface of $\mathrm{CaCO}_{3}$ particles was 
coated with either stearic acid or paraffin, most likely a result of the reduced inter-particular interactions.

The authors wish to thank ATOFINA Petrochemicals, Inc. (USA) for supplying s-PP resin, Calcium Products Co., Ltd. (Thailand) for supplying various grades of $\mathrm{CaCO}_{3}, \mathrm{Dr}$. Roger A. Phillips of Basell USA, Inc. for carrying out molecular weight and syndiotacticity measurements of s-PP resin, and Dr. Anuvat Sirivat and Wanchai Lerdwijitjarud of Petroleum and Petrochemical College for their kind suggestions on rheological measurement. PS acknowledges a grant provided by Chulalongkorn University through the Development Grants for New Faculty/Researchers. Partial support from the Petroleum and Petrochemical Technology Consortium and the Petroleum and Petrochemical College is gratefully acknowledged.

\section{References}

1. Ewen, J. A.; Johns, R. L.; Razavi, A.; Ferrara, J. D. J Am Chem Soc 1988, 110, 6255.

2. Natta, G.; Pasquon, I.; Zambelli, A. J Am Chem Soc 1962, 84, 1488.

3. Rodriguez-Arnold, J.; Bu, Z.; Cheng, S. Z. D. J Macromol Sci-Rev Macromol Chem Phys 1995, C35, 117.

4. Schardl, J.; Sun, L.; Kimura, S.; Sugimoto, R. J Plastic Film Sheeting 1996, 12, 157.

5. Sun, L.; Shamshoum, E.; DeKunder, G. SPE-ANTEC Proc 1996, 1965.

6. Gownder, M. SPE-ANTEC Proc 1998, 1511.
7. Sura, R. K.; Desai, P.; Abhiraman, A. S. SPE-ANTEC Proc 1999, 1764.

8. Guadagno, L.; Naddeo, C.; D’Aniello, C.; Di Maio, L.; Vittoria, V.; Acierno, D. Macromol Symp 2002, 180, 23.

9. Supaphol, P.; Spruiell, J. E. J Appl Polym Sci 2000, 75, 44.

10. Supaphol, P. J Appl Polym Sci 2000, 78, 338.

11. Stricker, F.; Bruch, M.; Mülhaupt, R. Polymer 1997, 38, 5347.

12. Stricker, F.; Mülhaupt, R. Polym Eng Sci 1998, 38, 1463.

13. Stricker, F.; Maier, R.-D.; Bruch, M.; Thomann, R.; Mülhaupt, R. Polymer 1999, 40, 2077.

14. Pukánszky, B.; Fekete, E. Polym Compos 1998, 6, 313.

15. Graf, D. L. Am Mineral 1961, 46, 1283.

16. Miser, D. E.; Swinnea, J. S.; Steinfink, H. Am Mineral 1987, 72, 188.

17. Rybnikar, F. J Appl Polym Sci 1991, 42, 2727.

18. Supaphol, P. J Appl Polym Sci 2001, 82, 1083.

19. Lovinger, A. J.; Lotz, B.; Davis, D. D.; Padden, F.J. Macromolecules 1993, 26, 3494.

20. Auriemma, F.; De Rosa, C.; Corradini, P. Macromolecules 1993, 26, 5719.

21. De Rosa, C.; Auriemma, F.; Vinti, V. Macromolecules 1997, 30, 4137.

22. De Rosa, C.; Talarico, G.; Caporaso, L.; Auriemma, F.; Galimberti, M.; Fusco, O. Macromolecules 1998, 31, 9109.

23. Supaphol, P.; Spruiell, J. E.; Lin, J.-S. Polym Int 2000, 49, 1473.

24. Maiti, S. N.; Mahapatro, P. K. J Appl Polym Sci 1991, 42, 3101.

25. Tjong, S. C.; Li, R. K. Y.; Cheung, T. Polym Eng Sci 1997, 37, 166.

26. Riley, A. M.; Paynter, C. D.; McGenity, P.M.; Adams, J.M. Plast Rub Proc Appl 1990, 14, 85.

27. Kim, K. J.; White, J. L. Polym Eng Sci 1999, 39, 2189.

28. Wang, Y.; Yu, M.-J. Polym Comp 2000, 21, 1.

29. Einstein, A. Ann Phys 1906, 19, 289.

30. Einstein, A. Ann Phys 1911, 34, 591.

31. Li, L.; Masuda, T. Polym Eng Sci 1990, 30, 841. 